\title{
Encounters and Engagement in the Civilizational Analysis of Japan
}

\author{
JEREMY C.A.SMITH*
}

Setkání a vzájemnosti v civilizační analýze Japonska

\begin{abstract}
As a field of significant activity for historical sociologists in recent decades, civilizational analysis has produced extensive and incisive works examining Japan as a historical formation of Eurasia. However, the same cannot be said of Japan's Pacific relationship with the United States, which is neglected in the major historical sociologies of Japanese modernity. This essay seeks to address that unnecessary oversight by putting that relationship into focus as an international dimension of the institution of both states. It would be tempting to elucidate the entanglement of the two as an encounter of civilizations, but the author instead casts it as intercivilizational engagement, that is a deeper set of connections generated by routine contacts and migratory movements, trade in commerce and culture, and selective appropriation of models of statehood. Delineating the lines of exchange in all four domains of connectivity between Japan and the US, the essay profiles the international and imperial extensions of both states. In altering the perspective on Japan's relations with the world, the author outlines a larger potential historical sociology of intercivilizational engagement between two Pacific-edge civilizational constellations.
\end{abstract}

Keywords: civilizational analysis; the Pacific; migration; international relations; capitalism; technoscience

DOI: $10.14712 / 23363525.2021 .16$

\section{Introduction}

Civilizational analysis and historical sociology have rightly regarded Japan as a sui generis modernity, a case study in divergence from Western statehood, and a civilization with deep roots in East Asia. This essay addresses a gap in historical sociology and largescale studies of civilizations, when it comes to Japan's relations with the Pacific world and particularly the United States. My direct claim relates to the relationship between the two nation-states and civilizational forces. I argue that from the mid-nineteenth century to the end of the twentieth century, what I term intercivilizational engagement entwined Japan and the US in rivalry, antagonism, strain, and collaboration. Following an outline of historical perspectives on Japan and my own work on "intercivilizational engagement", I treat this relationship of dense interaction and exchange in four stages. First, I examine trans-Pacific and circum-Asia migration. Then, I track inter-state relations between the US and Japan before the Pacific War. With a focus then on economic engagement, I highlight the competition of two interconnected models of capitalism in the postwar period.

* Dr. Jeremy C. A. Smith, Associate Professor of Sociology, Federation University, Mt Helen Campus, 3350 Victoria, Australia. E-mail: jeremy.smith@federation.edu.au 
A final section explores technoscience considered here as a pronounced factor of cultural engagement. In short, this essay is an outline of a potential historical sociology of intercivilizational engagement across the Pacific between America and Japan.

\section{Civilizational Analysis, Japan}

There are three major voices in civilizational analysis when it comes to comparative perspectives on Japan: S. N. Eisenstadt [1996], Robert Bellah [2003], and Jóhann P. Árnason [1997, 2002]. Each brings distinct propositions to common problematics of civilizational continuity and discontinuity, Japan's historic relationship to China, and questions of the ontological and non-axial character of this civilization. The last problematic has dominated debate. Eisenstadt contends that Japan's distinct ontological premises have shaped the de-Axialization of universalistic worldviews as the nation's historical experience [Eisenstadt 1996]. At the heart of this was the formative encounter with China in the seventh century, which endowed Japan with religious, linguistic, courtly, and intellectual traditions in a de-Axialized form. In social relations and state formation, Japan diverged from China. Segmented and relatively autonomous regionalism (under the symbolic umbrella of the emperorship) distinguished Japan from China. While protests and rebellions were common enough, utopian movements did not gain much traction due to the de-Axialization of universalist outside ideologies. Similarly, the ontological patterns of relativization of universalist ideologies and doctrines continued in modernity. Elements of the latter are often absorbed and transformed ("Japanized"), be it currents of Christianity or Marxism. Notwithstanding engagement with the outside world, Japanese civilization retains a situational orientation.

Like Eisenstadt, Bellah posits significant continuities in Japan's particularism [Bellah 2003]. Indeed, his emphasis on particularizing tendencies is even stronger, leading him to classify this civilization as "non-Axial". This is an ontological core with an orientation towards immanence more than towards external encounters, in Bellah's estimation. His specific interest is in durable religious traditions capable of muting conceptions of transcendence. In returning to themes of his earlier work on religion in Japan [Bellah 1985], he accentuates a finding that foreign master doctrines coexist with native cultures, but always in a subordinate state and unable to spark cultural transformation. On this point, his position is different to Eisenstadt's, yet also ambiguous. Mostly, he emphasizes Japan's non-Axial condition. Yet, in some respects, he perceives Japanese particularism as "pre-Axial", in other words archaic and not subject to any Axial effect [Bellah 2003: 7-8]. In his eyes, the potential for societal and political change is low, due to the fixed position of Japan's ontological premises. No phases of worldly encounter or degrees of intercivilizational engagement can shift this robust civilization from its fundaments.

Civilizational encounters find the greatest prominence in Árnason's civilizational sociology [Árnason 1997, 2002]. Japan's historical trajectory was punctuated by episodic hermeneutical reinterpretations of its imaginary significations of wealth, power, and meaning. This entailed phases of renegotiation with the regional environment, which was mostly, but not exhaustively, a China-centered East Asia. In Japan's long modernity, a growing awareness of an expanded world increasingly entered the thinking of political and religious elites and intellectuals as a second orientation. The multidimensional nature 
of modernization processes added complexity and several twists to Japan's twentieth century fate. Readers new to Árnason will immediately notice the accent on discontinuities. Likewise, in his re-theorization of categories of core and periphery, he demarcates a flexibility in the shifting figuration of culture and power not present in Eisenstadt's magnum opus (and precluded from Bellah's account of a decentralized civilization) [Árnason 2002]. In other words, Árnason's civilizational analysis of Japan diverges more markedly from the others on factors such as the kinds of continuities in history and the transformative effects of world engagement.

None of these perspectives give sufficient concrete attention to the Pacific horizon of Japanese civilization or indeed the modern relationship with American civilization, although all three have openings to both problematics. From here, I therefore outline my particular framework of civilizational analysis in order to lay the theoretical groundwork for such an exploration of trans-Pacific relations in modernity.

\section{Civilizations in the World}

In other work, I have examined the renaissance of civilizational analysis with a particular focus on Árnason and Eisenstadt's contributions [Smith 2017]. My approach seeks to emphasize "intercivilizational engagement" as differentiated from Nelson and Árnason's notion of intercivilizational encounters. In brief, I contend that the creation of civilizations in existing and emerging imaginaries becomes meaningful at the point of connection between constellations of societies. It is in the routine agency of mobile social actors that we find deep engagement composing connections and connectedness. The commerce in goods, ideas, scientific and theological doctrines, models of rulership and law, and practices of creativity add up to an interlinkage between the major civilizational regions of Eurasia, as well as other regions less examined in civilizational analysis. To be sure, there are barriers to relations and cases of detachment, most notably inter-state animosity, rivalry, and warfare. Yet, I estimate that it is quite valid to regard even the obstructions to deep engagement as relational orientations of a certain kind. One of the insights produced by global historians - which we historical sociologists can take careful note of - is that the manifold linkages of civilizations are evident further back in human history than previously surmised.

This conception of intercivilizational engagement is complementary to the analytic of intercivilizational encounters. Indeed, where the degree of engagement is at its densest and most regular, one can discern intercivilizational encounters. My focus is on the more pervasive forms of connection. Intercivilizational engagement can be mapped across four dimensions: migration; exchange in economic relations; cultural traffic; and political borrowing and transaction. While a detailed account of each is beyond the current essay, I can give an outline of trends. Migration has been a central impulse in species self-creation, not only in the form of expansion into new spaces (particularly in primary and Ancient movements), but also in, at times, fostering intercultural encounters. There is no evolutionary or linear pattern. However, the rate and volume certainly increased in the second millennium $\mathrm{CE}$ in all world regions. Modern migrations were religious or linked to imperial expansion, or could be part of settler-colonialism, or diasporic. Slavery and other modes of servile labor have defined a whole component of modern movement. 
Like migration, archaeologists and historians have begun to attribute the commencement of long-distance trade to a much earlier period than previously. A map of major historical trade zones would have different cartographic emphasis to most maps. It would need to highlight the Indian Ocean's long-term trade, the so-called Silk Road, Southeast Asia as integrated by Chinese and Indian merchants with other trade, and the outgrowth of commerce following conquest of the Americas and the intrusion of Europe's colonial empires into Asia. With trade came networks, trust-based social capital, and more extensive use of money, all extending over greater distances and across more cultural areas. To these social historical constellations, modern capitalism brought an imaginary of markets, money, accumulation, and profit. Although the integration of civilizations into world capitalism has occurred within a singular imaginary, prevailing constellations perpetuate varieties of economic order. Far from being subsumed by capitalism, civilizations have contextualized processes of globalization differently.

Cultural traffic in intellectual, religious, and aesthetic goods has stimulated centers of intercivilizational engagement. Looking at the major world regions through a lens of cultural exchange, most civilizations encompass multiple centers of knowledge that rely on the creative contest of ideas and intermittent paradigmatic reinvigoration from outside influences. Temples, schools, academies, monasteries, and universities have been magnetic centers attracting, producing, and diffusing knowledge and creative practices [Collins 2000]. Sustained intercivilizational encounters are often visible in the cultural outcomes they produce. Such production is possible because of underlying patterns of cultural interaction.

The final dimension is political exchange of elements of civilizational models. Empires operative in regional worlds variously contextualize what might in some cases be an exchange of civilizational elements, in others an imposition, and in some instances, outright emulation. How engagement of this kind unfolds is context dependent and there is significant variation between different civilizations. A pertinent example is the first millennium CE outgrowth of Chinese influence. Incorporation of Korea, Vietnam, and Japan into a broad Sinosphere led to emulation of China's model of rulership and law, but also internal innovations and refinements to the Chinese polity. This would prove a crucial encounter for Japan resulting from the densification of engagement in this dimension.

While this is only a brief recounting of the framework, I have so far outlined my conception of intercivilizational engagement in order to pave the way for an evaluation of Japan's modern relationship with the US. In my research on Japan's intercivilizational engagement, I have examined encounters and engagements in the Meiji era [Smith 2002; 2017: 169-172] and in the imaginary institution of Japanese capitalism [Smith 2014]. I have also engaged in deeper analysis of Árnason's unique historical sociology of Japanese modernity, state formation, and capitalism [Smith 2011]. My point of departure with Eisenstadt, Bellah, and Árnason has to do with Japan's long encounter with the West. In the late nineteenth century, the intensity in this encounter not only brought about major internal transformation, it altered the magnitude of the known and engaged outside world. The intercivilizational encounters and engagement with the US was one specific side of this, one less explored in historical sociology.

In the remainder of the essay, I sketch the contours of intercivilizational engagement by, first, demarcating modern migration as a single dimension of the trans-Pacific relationship 
and, second, briefly exploring aspects of the other three dimensions across three phases, namely the economic, cultural, and political. In a second section, I examine diplomatic relations from the 1890s to the invasion of Manchuria in 1937 as an example of political engagement. After short remarks on the creation of competing historical memories of the Pacific War, I explore the problematic of rival and entangled models of capitalism before, leaving for a final section, technoscience as cultural exchange. There is no claim here to a deep analysis. Rather, the essay is a probe into the major dimensions of the relationship of the US and Japan.

\section{Migration}

Japan has never accepted immigration as a developmental force. That said, there are notable aspects of modern emigration and selective channels of immigration that have defined the margins of national identity and are not to be overlooked. Emigration began in the early Meiji era with dekasega sojourners settling in Hawaii and Korea. Through inter-governmental agreements, a strategy of emigration soon extended the network of migrant colonies to Peru and Brazil. Other agreements in the inter-war period created communities in Bolivia, Paraguay and around the Caribbean. Although not systematized through written agreement, considerable migration to the US occurred. Despite positive contributions to American society and economy from Japanese newcomers, the process of trans-Pacific immigration to California and Hawaii (where American emigrants were also heading in larger numbers at the same time) heightened diplomatic conflict. Hawaii became a flashpoint for both states since governments of both countries had geopolitical designs on the islands as a major outpost in the North Pacific. A first generation of emigrants (issei) responsible for creating a Japan-oriented community in Hawaii had an uneasy relationship with a second partly Americanized generation (nisei) [Masako 2008]. A complex cultural interaction between Japanese and American programs in education occurred in the 1920s, converging on common aims of Americanizing the émigré population [Monobe 2008]. With an eye on improved trade and diplomatic relations between the two Pacific powers, Japanese-Hawaiians tried to support assimilation and thereby solicit goodwill towards the community. Instead of consolidating the local community, this moved many nisei to join Japanese migrants in California by relocating to the West Coast. Such immigration shifts added to domestic tensions on the mainland. Flows from Canada and Hawaii to Washington, Oregon and Southern California in the 1890s invigorated anti-Asian racism and led to diplomatic spats between the Japanese government and Theodore Roosevelt's administration [LaFeber 1998: 87-90; Dower 1999: 54-57; Davidann 2007: 83-95]. Japanese immigration had gained momentum in the wake of the 1882 exclusion of the Chinese. However, port and border closures arising from the 1924 Exclusion Act then precluded the Japanese too and intensified Japan's doubts about America's stated commitment to principles of universalism [Dower 1999: 144-146; Davidann 2007: 95-104]. Two generations of Japanese remained, some fifty thousand, endogenously forming a bi-racial west coast community. In between, wartime was made a jarring experience by internment. American reaction to Hawaiian and Californian Japanese present on US territory was a deeply dehumanizing distrust of the latter's patriotism [Dower 1999: 219-222]. Despite this, the larger community reassembled in Hawaii and California after 
the War. Japanese Americans in time became part of a larger Asian-American constellation concentrated in the western states.

The story of emigration is one thing: Japan's record on immigration, quite another. Despite deep historical experiences of formative migration, modern dynamics reveal, at most, highly selective intakes of migrants from delimited sources. For the first time since the 7 th century, substantial Korean migration occurred during Japan's early twentieth century colonization of the Korean peninsula. Much occurred under compulsion. Migrant workers came in large numbers to Osaka, Hiroshima, and Nagasaki as low paid industrial workers [Komai 2001: 13-14; Weiner 1997: 84-91]. Although less connected to colonization, Chinese migration nourished communities with a discrete standing in society stemming from their business networks in Southeast Asia and Taiwan. Both foreigner communities consolidated an urban presence in the first five decades. They did not benefit proportionally from industrial re-development, yet they were variously reincorporated into the workforce and small business sector. Their urban and economic presence was constant, despite systematic political and cultural exclusion.

In response to economic growth, foreigner communities of Koreans (zainichi), "returnee" Japanese (nikkeijin), Chinese, and American-Japanese (to a far lesser degree) contributed to the institution and recreation of national identity, despite being peripheral to the monocultural mainstream and continually suffering from denial of citizenship and discrimination in employment, education and housing [Komai 2001; Murphy-Shigematsu 1993]. Far from vanishing, they are increasing in number. Non-Japanese communities doubled in size in the two decades after the wane of nikkeijin return migration in the 1980s. Although they remain small, the comparatively youthful demographic profile of nikkeijin communities is at odds with the ageing population. Movements of return-Japanese from Latin America stimulated a marginal diversification of culture and society in the 1980s and 1990s [Sellek 1997]. Drawn by higher incomes than in their countries of origin, migrants crossing the Pacific bring histories of emigration back to their ancestral home, adding to a greater heterogeneity than is often attributed to Japan. Nikkeijin still suffer discrimination. Although included in the legal definition of nationality as Japanese, many treat nikkeijin as Brazilians, Peruvians etc. Their presence unsettles Japanese notions of race [Sellek 1997: 201-204].

Disavowal of open migration has left Japan with demographic stagnation to match the languor of its economy since the early 1990s. Even so, the history of governmental policy in migration is more nuanced than the official position suggests. Illegal immigration has become a large-scale phenomenon since the late 1980s. Coupled with growing foreign student programs, it adds to the multi-ethnic diversity of the urban population in Osaka, Nagoya, and Tokyo. Research on minorities reveals that Japan's population is ethnically composed in ways comparable with industrial societies on a world scale [Murphy-Shigematsu 1993; Sugimoto 2014]. The flows of migration as part of intercivilizational engagement reveal a more nuanced picture of race and population than monocultural images of singular and dominant ethnicity would suggest. The growing multicultural paradigm of race, culture, and ethnicity seems to reflect more exactly the degree of diversity. For a more complex historical sociology of migration and cultural exchange and transfers, the contribution of the multicultural social sciences is an important counterweight to a modern history of monoculturalism. 


\section{Entanglements in Asia and the Pacific: War, Diplomacy, Invasion}

From the Pacific edge of the continent, Americans could picture themselves as a power in Asia. The Mexican War, subsequent settlements with Canada and Britain, and the discovery of gold in California marked a unification of continental territory for the US just prior to Commodore Perry's intrusion on Tokyo Bay. Reaching California, Americans looked poised to stretch much further into the Pacific. America had increased its presence in East Asia through the preceding decades with frequent ventures by whalers, missionaries, and unsuccessful diplomats [LaFeber 1998: 8-13; see also Sexton 2011: 114-115]. To the private presence of American adventurers, the US state would add its own interventions as a public power. With the newfound confidence of a continental nation, Atlantic America acquired a Pacific horizon in the 1850s and quickly mustered its maritime power in engagement and negotiations with Japan and China.

Up until the 1898 war with Spain, diplomatic affairs and economic and cultural transactions between Japan and the US relationship were competitive yet congenial. The two states became more deeply entangled. At home, the US was engaged in Reconstruction, enlarging its national economy, and building up its rapidly growing western population. On the other side, Japan was fast building its national base and expanding influence overseas. In the late 1890s, an empowered America became more actively involved in the Asia-Pacific in an urgent attempt to check the European powers in China, maintain practices of open trade, and build its naval power [LaFeber 1998: 57-62]. At this time, containing Japan was the only kind of diplomatic pressure that the McKinley Administration could apply, and it intentionally did so. Fortunately, for the United States, success in the war with Spain delivered a major foothold in the Pacific, considerably strengthening its diplomatic strategy of containment. Guam, American Samoa, the Philippines, Hawaii and, in the Americas, Cuba, the Panama Canal, and Puerto Rico all fell to the Americans in a six-year period. The US was suddenly in command of two major spheres of influence, in effect creating an interregional bridge between the Americas and the Pacific. The political orientation of the Republican government that defeated Spain was evidently expansionist. In discussions to move swiftly to annex the Philippines and Hawaii, McKinley spoke for this orientation, when he expressly invoked "Manifest Destiny" [LaFeber 1998: 60], as a reminder of the US' newfound expansive capacity and its goals.

Notwithstanding the ambitions of the US government, development of American interregional power ran into significant limits in the Pacific in the early twentieth century. Japan had become a fast-emerging rival, curtailing the enlargement of American influence. Public opinion was also a constraint on American action. Influential constituencies favored cooperation with Japan more than naked assertion in the region [Davidann 2007]. Diplomatic negotiations were, moreover, limited in their results. Other European powers advanced their own interests and shared little in common with the US. American diplomats in turn argued in favor of free trade in China and Japan and yet could make no ground. For their part, Japan's diplomats did not fail to remind their American counterparts of how possession of the Philippines was irreconcilable with the ideals of the Monroe Doctrine [Davidann 2003: 25]. Furthermore, formal American possession of overseas territories halted after seizure of the former colonies of Spain. Only in Hawaii's case was the US in such a position that it could turn the degree of asymmetrical connectedness into 
a strategy of steady incorporation [Davidann 2008]. Overall, in the lead-up to World War 1, the operative obstacles to American penetration of the Asia-Pacific region proved to be insurmountable.

From this time through to the Pacific War, Japan intensified its observations of the strategies of state building undertaken by the leading imperial states. This proved valuable in its own project of building military-imperial power. In the early twentieth century, the Japanese benefitted from the demonstration effect of two kinds of empire. The colonialism of Europe's world empires defined the first type. The second example was the US - a power renouncing colonialism, if not the occupation of a few territories within its Atlantic and Pacific spheres. Both types of empire had a heavy presence in Asia and the Pacific. Western powers were themselves rivals as well as collaborators. Amongst them, the US stood out for its public renunciation of colonialism. Learning at a certain distance from the US as well as the colonial empires gave Japan another angle on international relations. The institutional composition of Western states and the universe of Western statehood were important objects of study in discerning strategy in foreign policy, and military development.

The relationship of Japan and the US shifted in the interwar period. Woodrow Wilson admonished the major powers to refrain from colonial possession in Asia [LaFeber 1998: 114-115]. Accordingly, the US diplomatically pursued multilateral agreement around "open door" principles of free trade in respect of China and Japan. To curb American efforts, Japan responded with a reassertion of the racial equality clause that it had sought at the Versailles negotiations. On the face of it, this was a symbolic principle that would improve its diplomatic position in Asia and the Pacific, and indeed with the imperial European powers. At a deeper non-epiphenomenal level, it was part of an emerging civilizational vision that would conflict with that of the US in the 1930s [Davidann 2003]. America's lack of headway in trade with China and Japan frustrated Washington's strategy and added to tensions with Japan. With the gap between the two powers growing, the Japanese, who for years had been better disposed to the distinctive American way, increasingly turned on the US, grouping it indiscriminately with the European powers [Davidann 2007: 81-82].

Tokyo's own strategy fixed firmly on development of an imperial-national state built on the back of a two-sided relationship with East Asia. On one side, its industrialization became more dependent on inputs from its colonies as the years progressed. On the other side, civil and military leaders sought to strengthen the nation-empire's strategic position $v i s-\grave{a}$-vis the US and, indeed, the faltering French and British Empires. Expanding the bureaucratic capacities of the state was both a nation and empire-building priority for Japan's elites. By extending additional capacity into the region, they risked opposition from the US, Britain, and France. Yet, none of the contending empires could mount a challenge for supremacy in Asia as Japan could. The Depression had severely weakened their rivals' domestic heartlands in Europe [Árnason 2002: 188]. Knowing this, Japanese officials even toyed with the idea of forging a Monroe Doctrine of their own [LaFeber 1998: 177-178, 92-93; see also Davidann 2007: 159-160]. They did not proceed; yet even entertaining the idea shows growth in their level of self-confidence. Their alternative, the Greater East Asia Co-Prosperity Sphere, reflected the empire's unusual coupling of the colonies' labor and raw resources to a logic of industrial-capitalist development in Honshu. Doubtless, this represented regionalization. Yet, it was a regionalizing logic of a kind quite distinct from the Monroe Doctrine. In the end, the military confrontation with the US in the Pacific 
undercut its viability. The relationship of both countries, which had been competitive yet congenial before 1898, became increasingly adversarial after World War 1, and then conflictual in the 1930s, ended in war in 1941.

While the Pacific War as a conflagration in the US-Japan relationship is beyond the current essay, one brief observation on memory and commemoration of the conflict is in order, as the memory of war represents a very particular episode in ongoing cultural engagement between the two powers. In the postwar era, both sides constructed an inverse and adversarial historical memory [Dower 1999]. What one side remembered; the other side suppressed. By the 1990s, social memory of the war had also become a controversy of commemoration. To put this in terms consonant with Jan Assmann's theorization of memory, communicative memory (connected to the lived experience of events) had turned to cultural memory (captured in institutions of commemoration - museums, statuary, art, memorials) [Assmann 2011]. Far from fading, debates about the Pacific War became more animated as memory became memorialized. Ambiguity about the memory of the atomic bombing at Hiroshima and Nagasaki troubled Americans and plagued shrill-pitched debates about the commemoration of the end of the war. In one controversy, it became evident that what lingers low-key in Japan's historical memory is prominent in the US [Hein 1995; Neiman 2015]. That controversy concerns a 1995 exhibition at the Smithsonian Institute. The Institute and its curators had to back down from depiction of the horror of the bombing following congressional pressure. They agreed instead to a fuller portrayal of Japan's barbarities in Asia. This is the inverse of Japan's commemorative representations, as exemplified at the Peace Park museum in Hiroshima, which revolves around the atomic bombing while muting collective memory of the record in Asia. Japanese commemoration places a stress on the momentous and unparalleled experience of the country's defeat and desolation, leaving it the victim - an experience which belongs to Japan only [Dower 1999].

While there was a great deal of noise and heat in the 1990s shrill culture wars in the US about the memory of the war, governments of both sides also adhered to selective silences about the past. America's postwar recovery of the imperial institution, the suffering of wartime internees of both sides, and the war's disproportionate impact on Japan's minority communities were not up for debate. Despite Japan's relative economic decline in the 1990s and into the new century, there is little sign that this has abated. Divergent historical memories of the Pacific War remain, despite an alliance that strategically serves both countries in the face of China's ascendancy.

\section{Cooperative, Interlaced, and Competing Capitalisms}

If one wishes to posit a "clash" of the two states, as La Feber does [LaFeber 1998], then there can be little quarrel with the proposition that economic relations between the two are both adversarial and cooperative. Both kinds of relationship are evidence of the entanglement of rival national economies. Capitalism has produced in each national economy, and each economic sphere of influence, different and competing models of industrial and post-industrial development with diverging cultural traditions [Árnason 2002: 185-199; Lipset 1993]. Both have spheres of influence entailing Asia. As we see in the previous section, Asia was central to Japan's trajectory in the 1930s and 1940s. Asia became special again for Japan after the war in a way unmatched for the US. 
American policy makers may have repeatedly made designs on an "open trade" Asia in the first half of the century. But these finally petered out in the new geopolitical environment of the Cold War, especially after the occupiers turned towards economic policies promoting renewal in order to bolster Japan's role as a bulwark against Communism in Asia. Wartime universalist visions of the American Century and the Atlantic Charter faded as Cold War imperatives made a prosperous and stable ally in East Asia a priority for the Eisenhower, Kennedy, and Johnson Administrations. Free trade was certainly not the result. By favoring Japan with a huge procurements program during the Korean War, access to licenses for patents on new technology, training in labor management and quality control, and special terms of trade, industrialized America offered support to its new ally that it chose to offer to no others [Morris-Suzuki 1994: 166-169]. When it came to reconstruction of a conservative bloc of peak business bodies, a political party, and the public bureaucracy, the American position varied from overt support to timely acquiescence. With stability assured (so it seemed), rapid economic growth became possible. Indeed, this arrangement had been the hope of Japanese politicians and administrators from as early as 1946 [Dower 1999: 536-540; see also Eisenstadt 1996: 54-64; Árnason 1997: 492-502].

Conflict ensued, especially around the alliance with the US and the continued military presence in Okinawa. Yet, after the heady days of clashes between students, politicians, and the police in 1960, internal conflict suddenly abated. From that point, growth suddenly became staggering. The components of the "developmentalist state" were ready for continuous expansion and creative scientific and technological renewal [Johnson 1982; see also Morris-Suzuki 1994]. Japan's elites were enchanted with growth and managed to legitimize the objectives of periodic Economic Plans as a source of motivation for the population at large. If growth was an overarching aim and planning a mode of long term thinking and goal setting, then the necessary institutional components of the developmentalist state certainly existed. MITI and all the major ministries harnessed the financial power of the banks to selectively support export industries and develop strategies for the key groups of companies (keiretsu) to compete on foreign markets, especially in the US. A situation of industrial peace coupled with a management focus on worker motivation and loyalty also facilitated coordination. For more than ten years, American governments supported the relationship, bringing international validation to Japan's course.

American politicians and policy advisors had not asked too many questions about the economic benefits until the imbalance in trade, finance, and investment became too great to ignore. During the Nixon years, relations between the two countries increasingly became tense and protracted as differences over trade and foreign policy surfaced [LaFeber 1998: 327-395]. Disagreements over the Vietnam War and trade with the Soviet Union and China were no longer quietly set aside. When it became evident that Japan had weathered the 1973 oil crisis through large-scale public spending and increased keiretsu investment in China and Southeast Asia, it became too much for Americans to bear as they watched their own domestic economy slump. This phase of mild antagonism was further compounded by ascendancy of Korean, Taiwanese, and Singaporean versions of capitalism in the wake of Japan's success. With other models of capitalism emerging, the relationship of the two trans-Pacific allies got on to a more competitive footing [Katzenstein - Shiraishi 1997]. In this period, Japan launched a sustained effort to regionalize the 
major components of its production and service chains, a strategy that served to prolong rapid economic growth for another decade and a half. Although this provided the impetus for regional integration, the co-existence of competing national economies meant that open multilateralism was the order of the day. APEC was the result. Importantly, however, Japan's own regional production networks triangulated trade between South-East Asia, Northern Asia, and the United States, enhancing the interregional connection of the Americas to the Asia-Pacific.

By the time America's domestic economy had begun to rebound in the mid-1980s, the balance of economic engagement had altered. Public debt, a strong greenback, and an unprecedented imbalance in trade and investment with Japan and Asia prompted policy responses that worsened America's position [Dower 1999: 375]. The 1985 Plaza Accords, intended by the Americans to re-train Japanese decision-making and re-balance two national economies, failed spectacularly. Instead, Japanese companies held firm and absorbed the losses. Foreign investment in China, Southeast Asia, the US, and Australia increased dramatically on the strength of the yen. In support of the growing presence, Japanese governments promoted a strategy of re-Asianization of the region under the umbrella of a still problematic and contested Japanese identity as a counterweight to US interests and influence. From this time through to the 1993 crisis, American public opinion diverged over Japan. Widely - and prematurely - perceived as the future giant of the world economy, Japanese capitalism appeared to be either a driving cause of American decline or the key to its renewal. At times, the American literature on the political economy of the relationship reflected hyperbole and dramatic oversimplification of a complicated historical entanglement (particularly when formulated by politicians or the media commentariat). More serious long-term observers and participants in trade negotiations and diplomacy, able to avoid the tense atmosphere advised successive administrations from Reagan to Bush to learn from Japan [Uriu 2009]. Major trade and policy experts and scholars such as Chalmers Johnson, Clyde Prestowitz, and James Fallows argued in the media for corporate and political reform. At the same time, more assertive trade negotiators from the American side didactically instructed the Japanese on the apparent benefits of neo-liberal reform of financial institutions and trade policy and practice. In a war of words, they assaulted the non-conformity of the developmental state, while their counterparts treated their advice with benign neglect. Economic rivalry threatened to undermine the political and military alliance with the US. That threat would fade at a new juncture for Japan in the 1990s.

The consistent economic growth Japan had enjoyed since 1960 became elusive in the new decade. In its place, Japan settled into the recognizable "peaks and troughs" of capitalist cycles. The fracturing of the LDP in the 1993 election disrupted the developmental state's architecture of bureaucracy, party, and business for a few short years. After that, the parts of the developmental state were still in place but the whole no longer acted as the center of gravity it once had. The LDP returned to government with no certainty that its monopoly would hold in the subsequent years. In this new environment, it looked like Japan would not commit to the neoliberal program variously preoccupying the political agenda of many governments in the 1990s. While there was no wholesale adoption of the project, important policies and measures of a neoliberal character did bring about a limited range of changes in the composition of Japanese capitalism [Lechevalier 2014]. Beginning with Hashimoto's 
administration in 1996, a series of reforms responding to shifts in the international and internal environment began to concentrate the attention of governments. We can name three here. First, the relationship with the US brought with it pressure around trade and security issues of the kind described above in the section on the late 1980s. That pressure continued during the Clinton and Bush years. In the international arena more generally, the demonstration effect of NAFTA and the EU had an indirect impact on Japanese deliberation, as did meetings and debates in APEC. The institutionalization of trade rules in the WTO was both an ideological and operational confirmation of the powerful position market economics held in the international arena. Finally, structural and policy reforms were intended to address the flat rates of growth, which emerged as a continuing crisis as the 1990s turned into the new millennium. Evidently, no return to the dizzy heights of 1960s growth was possible using old measures. Growth acts as both signification and index of the crisis - just as it had been the signification and index of postwar success. Through a pattern of small rises and two sharp contractions, Japan's average growth rates have remained stagnant. LDP governments attempted to address structural problems with financial deregulation, reform to corporate law, and labor market restructuring. The initiatives of the LDP in power since the end of the growth boom have undermined the traditional operational patterns of the developmental state without dislodging it altogether. However, continuity in the formulation and implementation of a consistent reform program has been hard to find. Arguably, Koizumi's administration has represented the most sustained effort. Even here, the LDP faced institutional blockages and public opposition around specific proposals. In the meantime, growing organizational diversity in business and finance sectors, along with segmentation of the labor market, have been important secular shifts, but far from the wholesale transformation that would suggest a trajectory of convergence with other models of capitalism, including that of Japan's trans-Pacific partner.

Overall, Japan still sustains a variety of capitalism that leads most national economies. With its national focus on Asia growing and economic rivalry with the US tapering off from its peak levels, Japan has enjoyed a less combative trade and strategic trans-Pacific relationship. An increase in shared security interests in the new century has brought both powers closer together. Both countries - one embodying the largest and the other the third largest national economy in the world - have oriented steadily to an Asian capitalism outgrowing Japan and extending its global economic reach to all continents and major zones of the world: China. The story from there is well known.

\section{Technoscience, Creativity, and Cultural Interchange}

A component of the model continuing through the crisis and into the present is technoscientific creativity and innovation. In this concise section, I explore technoscience as a pronounced factor of cultural engagement between Japan and the US. The larger-scale transfer of American technology in the 1950s and 1960s was possible because of two factors. The first is Japan's geostrategic importance in the Cold War, as discussed above. Second, an established orientation to scientific endeavor across business, industry, and government revived during the Occupation. High levels of literacy and education and a diverse skills base in the blue-collar and professional workforce enhanced the orientation to science. 
The orientation to science has a pre-history. Meiji era Japan had itself been a beneficiary of Tokugawa-era learning. Beginning in that time with a creative adaptation of Western technologies, industrial techniques, and engineering expertise, Japan has enchanted technoscience and privileged pure research [Morris-Suzuki 1994]. This imaginary orientation had an operational life in networks of major universities, scientific institutes and laboratories, and in small firms and zaibatsu groupings linked to foreign companies and international science. Up until the 1930s, an innovation-based process of industrialization advanced rapidly, in part due to connection with the technological breakthroughs made by Western companies (including American ones). In the hands of Japanese industrialists, Western technologies would be dramatically re-purposed. In addition, scientists and zaibatsu companies invented original technologies and new approaches to technical education, the organization of production and the labor process, particularly when supported by government planners [Morris-Suzuki 1994: 116-141]. Some of the most important developments had dual use. In the environment of military rule, combat use often prevailed. Although pre-war developments were crucial, the zenith of invention would await the postwar takeoff. War and defeat had led many to the conclusion that Japan lost to the West due to a deficit of scientific rationality [Dower 1999: 494-496]. Japan in "the postwar" would be a country oriented to the "rational" use of science, which in turn would immunize the nation against an irrational return to militarism. With the Occupation over, Japan could set about assiduously learning from America after, just as some in the US could absorb aspects of Japanese production techniques and quality control and management regimes in the 1970s and 1980s. Investment from philanthropic foundations in Japanese university education and large-scale provision of places for exchange students in American universities set up an interchange of knowledge across the Pacific that would last decades [LaFeber 1998: 300]. Japan's scientific development was a national priority. Investment in research and development dwarfed the funds spent on license purchases in the 1950s and 1960s, revealing that MITI and the major industrial groups privileged the development of technological and scientific networks [Morris-Suzuki 1994: 170-187]. New networks shared the results of research and development with groups of companies, setting the industry and service sectors on a different footing to their pre-war counterparts. In doing so, they modeled a new nexus of science and industry. In the postwar paradigm of re-industrialization, cooperation brokered by MITI and other ministries underpinned advancement. Science had an especial role in this figuration.

This public/private partnership interwoven over a sustained period has few parallels [Low - Nakayama - Yoshioka 1999]. Yet, the pattern was not even across the postwar decades. It was mainly after the 1973 oil crisis that investment in general science and applied research and development intensified, as the country oriented to greater technological self-reliance [Morris-Suzuki 1994: 210-212]. To some extent, the mantra of growth then had a companion in the privilege accorded to the re-enchanted sphere of science. The partnerships linking science, bureaucracy, and industry had already established a supportive ecology for technoscientific invention. At times, unusual alliances of industries found commercial applications for the findings of pure research, where government-led initiatives could not. Altogether, the creative dynamism of the research and development environment helped to foster debate about scientific logic itself, as well as generating invention and inventiveness. In this sense, Japanese ingenuity could contribute to global science, as well as domestic development. 
From the 1980s onwards, emerging industries in biotechnology, robotics and environmental technologies turned to exports [Morris-Suzuki 1994: 239-244]. Through exports of electronics, Japanese industry had already revealed its capabilities. New inventions from emerging industries washed through the economy, even as the leading corporate groupings shipped their inventions around the world. The direct impact that diffusion of technologies had was limited, yet the intangible contributions in digitalization cannot be underestimated [Morris-Suzuki 1994: 213-224]. The power of Japanese microelectronics added significantly to the exponential growth of digital memory, which has continued in the 21 st century on the back of increased expenditure in research and development (in both absolute and relate terms) Partnerships with universities augmented the commitment of large corporations to research. However, they did so without detracting from endeavors in pure science emphasizing a curiosity-driven research and not only instrumental outcomes. At the same time, the spread of Japanese mass culture was another domain of digitalization. Through export of digital products (games, anime, manga), the new culture industry disseminated trans-cultural Asian identity, even as the products acted subtly as carriers of Japanese values.

Aside from Asia, North America is the main destination for the goods and by-products of Japanese science. Companies in the US absorbed aspects of Japanese production techniques and quality control and management regimes, sometimes wholesale, yet often piecemeal. American manufacturers that adopted lean production technologies and organizational systems in the 1980s and 1990s are a significant case in point. Overall, technology transfer in the US has been more extensive than in Southeast Asia. However, there was also a more diffuse immaterial impact. The intangible spread of the example of scientific advancement set industrial-capitalist nations in a condition of invention, learning, absorption, and emulation of scientific and industrial research. Japan touched a competitive nerve in other industrial economies, in turn stimulating competitive innovation. This is especially so for the US, which has been a recipient of the indirect benefits of Japanese technology.

Not all has been success. Some of Japan's technoscientific utopianism has not produced the results it seems to promise (many plans for utopian cities were shelved decades ago, for instance). Nevertheless, science in the sphere of cultural engagement has undoubtedly been one of the keys to the accomplishments of post-Occupation ascendancy. Science has been central to the developmental state and the creation of a distinct variety of capitalism. The relationship with the US - rival and ally both at once - has contributed to this area of cultural engagement.

\section{Conclusion}

Japan is a civilization of the East Asian constellation. At the same time, Japanese modernity incorporates relationships with modern states of the Pacific and the Americas. Being instituted with these relationships, modern Japan has Pacific horizons demarcated largely by intercivilizational engagement with the United States. American civilization a force of Atlantic modernity - was born a continental nation also with Pacific horizons. Its intercivilizational engagement with the Pacific deepened after the war with Spain in which it obtained former Spanish possessions in the Western hemisphere and the Asia-Pacific region. If the possibility of an American colonial empire passed quickly, the presence of 
the new world power in the region did not. In the twentieth century, the relationship of rivalry, antagonism, strain, and collaboration with Japan has been crucial for America's position in the region. Indeed, it is no exaggeration to say that the relationship has been mutually transformative for both sides. As presented in the current essay, my outline of how this relationship runs through the four dimensions of intercivilizational engagement is suggestive and not comprehensive. A more detailed account of emigration and selective immigration, economic connections, cultural exchange, and transfers of techniques and ideologies of rulership and statehood is a larger project. Nevertheless, one conclusion can withstand scrutiny. In Japan's interface with the Pacific, engagement with the US has been definitive, while for the US, long-term interaction with Japan has been a focal point of its orientation to the Pacific. A history of modern intercivilizational connectivity between the two Pacific edge worlds awaits a deeper reconstruction.

\section{Acknowledgements}

I would like to thank Jóhann Árnason for his extremely helpful feedback and recommendations on readings. My thanks also to Dr Strobe Driver for past conversations on the relationship between the United States and Japan.

\section{Bibliography}

Árnason, Jóhann Páll [1997]. Social theory and Japanese Experience: the Dual Civilization. New York: Kegan Paul International.

Árnason, Jóhann Páll [2002]. The Peripheral Centre: Essays on Japanese History and Civilization. Melbourne: Trans Pacific Press.

Assmann, Jan [2011]. Communicative and Cultural Memory. In. Meusburger, Peter - Heffernan, Michael Wunder, Edgar (eds.). Cultural Memories: the Geographical Point of View. New York: Springer.

Bellah, Robert N. [1985]. Tokugawa Religion: the Cultural Roots of Modern Japan. New York: Free Press.

Bellah, Robert N. [2003]. Imagining Japan: the Japanese Tradition and its Modern Interpretation. Berkeley: University of California Press.

Collins, Randall [2000]. The Sociology of Philosophies: a Global Theory of Intellectual Change. Boston: Harvard University Press.

Davidann, Jon Thares [2003]. Citadels of Civilization: U.S. and Japanese Visions of World Order in the Interwar Period. In. Jensen, Richard J. - Davidann, Jon Thales, - Sugita, Yoneyuki (eds). Trans-Pacific Relations: America, Europe and Asia in the Twentieth Century. Westport, CT: Praeger.

Davidann, Jon Thares [2007]. Cultural Diplomacy in U.S.-Japanese Relations, 1919-1941. Basingstoke: Palgrave Macmillan.

Davidann, Jon Thares [2008]. Hawaii at the Cossroads of the U.S. and Japan Before the Pacific War. Honolulu: University of Hawaii Press.

Dower, John W. [1999]. Embracing Defeat: Japan in the Wake of World War II. New York: W.W. Norton \& Co.

Eisenstadt, S. N. [1996]. Japanese Civilization: a Comparative View. Chicago - London: The University of Chicago Press.

Hein, Laura [1995]. Introduction: the Bomb as Public History and Transnational Memory. Bulletin of Concerned Asian Scholars 27: 3-15.

Johnson, Chalmers A. [1982]. MITI and the Japanese Miracle: the Growth of Industrial Policy 1925-1975. Stanford, California: Stanford University Press.

Katzenstein, Peter J. - Takashi Shiraishi [1997]. Network Power: Japan and Asia. Ithaca: Cornell University Press. 
Komai, Hiroshi [2001]. Foreign Migrants in Contemporary Japan. Melbourne: Trans Pacific Press. LaFeber, Walter [1998]. The Clash: U.S.-Japanese Relations Throughout History. New York: Norton. Lechevalier, Sébastien [2014]. The Great Transformation of Japanese Capitalism. London: Routledge.

Lipset, Seymour [1993]. Pacific Divide: American Exceptionalism - Japanese Uniqueness. International Journal of Public Opinion Research 5 (2): 121-166.

Low, Morris Fraser - Nakayama, Shigeru - Yoshioka, Hitoshi [1999]. Science, Technology and Society in Contemporary Japan. New York: Cambridge University Press.

Masako, Gavin [2008]. In Search of a New Identity: Shiga Shigetaka's Recommendations for Japanese in Hawai'i. In. Davidann, Jon Thares (ed.). Hawaii at the Crossroads of the US and Japan Before the Pacific War. Honolulu: University of Hawaii Press. Honolulu: University of Hawaii Press.

Monobe, Hiromi [2008]. Americanizing Hawai i's Japanese: A Transnational Partnership and the Politics of Racial Harmony during the 1920s. In. Davidann, Jon Thares (ed.). Hawaii at the Crossroads of the US and Japan Before the Pacific War. Honolulu: University of Hawaii Press.

Morris-Suzuki, Tessa [1994]. The Technological Transformation of Japan: from the Seventeenth to the Twenty-First Century. Cambridge - Melbourne: Cambridge University Press.

Murphy-Shigematsu, Stephen [1993]. Multiethnic Japan and the Monoethnic myth. MELUS 18 (4): 63-80.

Neiman, Susan [2015]. Forgetting Hiroshima, Remembering Auschwitz: Tales of Two Exhibits. Thesis Eleven 129 (1): 7-26.

Sellek, Yoko [1997]. Nikkeijin: the Phenomenon of Return Migration. In. Weiner, Michael (ed.). Japan's Minorities: the Illusion of Homogeneity. London: Routledge.

Sexton, Jay [2011]. The Monroe Doctrine: Empire and Nation in Nineteenth-century America. New York: Hill and Wang.

Smith, Jeremy C. A. [2002]. Theories of State Formation and Civilisation in Jóhann P. Árnason and Shmuel Eisenstadt's Comparative Sociologies of Japan. Critical Horizons 3 (2): 225-251.

Smith, Jeremy C. A. [2011]. Modernity and Civilization in Jóhann Árnason's Social Theory of Japan. European Journal of Social Theory 14 (1): 41-54.

Smith, Jeremy C. A. [2014]. Contexts of Capitalism: from the "Unlimited Extension of 'Rational Mastery" to Civilizational Varieties of Accumulation and Economic Imagination. In. Karalis, Vrasidas (ed.). Cornelius Castoriadis and Radical Democracy. Leiden: Brill.

Smith, Jeremy C. A. 2017. Debating Civilisations: Interrogating Civilisational Analysis in a Global Age. Manchester: Manchester University Press.

Sugimoto, Yoshio [2014]. Japanese Society: Inside Out and Outside. International Sociology 29 (3): 191-208.

Uriu, Robert M. [2009]. Clinton and Japan: the Impact of Revisionism on US Trade Policy. New York: Oxford University Press.

Weiner, Michael [1997]. The Representation of Absence and the Absence of Rrepresentation: Korean Victims of the Atomic Bomb. In. Weiner, Michael (ed.). Japan's Minorities: The Illusion of Homogeneity. London: Routledge.

Jeremy C. A. Smith is in the School of Arts at Federation University, Australia. His principal research interests lie in the disciplinary fields of historical and comparative sociology and social theory. He has published in European Journal of Social Theory, Current Sociology, Critical Horizons, Journal of Intercultural Studies, Atlantic Studies and Political Power and Social Theory. He is the author of Europe and the Americas: State Formation, Capitalism and Civilizations in Atlantic Modernity (Brill 2006) and Debating Civilizations: Interrogating Civilizational Analysis in a Global Age (Manchester University Press 2017). He is also a Coordinating Editor of the international journal Social Imaginaries (Zeta Books) and the Social Imaginaries book series (Rowman \& Littlefield). His current work revolves around the multidisciplinary fields of civilizational analysis and social imaginaries. 